\title{
IMPACT OF MACA (Lepidium meyenii) TREATMENT ON PRODUCTIVE PERFORMANCE, LITTER SIZE AND MILK YIELD OF RABBIT DOES OF DIFFERENT BREEDS.
}

\author{
T.M. El-Sheikh ${ }^{1}$, A.A. Abuoghaba**1, K.M.A. Ghaly ${ }^{2}$ and M. Kh. Wadeaa ${ }^{3}$ \\ ${ }^{1}$ Department of Poultry Production, Faculty of Agriculture, Sohag University, Sohag, Egypt. \\ ${ }^{2}$ Department of Animal and Poultry Production, Faculty of Agriculture, Minia University, Minia, Egypt. \\ ${ }^{3}$ Department of Animal Production, Faculty of Agriculture, Beni Suef University, Beni Suef, Egypt. \\ Corresponding Author: Prof Dr. Talaat Mostafa El-Sheikh; talaatm2@yahoo.com
}

(Received 7/5/2019, accepted 27/6/2019)

\section{SUMMARY}

$\mathrm{M}$ ost rabbit breeders suffer some problems during summer season such as fertility and litter size as well as increase feed costs. Litter size at birth and weaning are important economic traits, which determine the number of kits for future breeding programs and life-time productive. This experiment aimed to study the impact of Maca (Lepidium meyenii) capsules administration on body weight, feed consumption and milk yield of rabbit does as well as number of litter size, pre-weaning mortality and litter weight. Thirty-six rabbit does, from the breeds of V-line, New Zealand white and Bouscat, with 12 of each. They were divided equally into two equal groups of each breed. In the $1^{\text {st }}$ group, rabbits were fed a commercial breeder ration without any supplementation, while the $2^{\text {nd }}$ group were fed the commercial breeder ration and received daily oral does $500 \mathrm{mg}$ Maca capsule/doe before mating by one week. All does were re-administered with the same dose after three days from parturition for one week (day per day), then re-mated directly for the second and third parties. The traits measured were body weight and feed consumption of rabbit does. Also, number of litter size, litter weight, the pre-weaning mortality and the milk yield were recorded as well. The obtained results revealed that the body weights of $\mathrm{V}$-line and NZW rabbit does after treating and birth were significantly $(\mathrm{P} \leq 0.01)$ reduced than that of the Bouscat, while the means of daily and total feed consumption were not affected by rabbit breed. The litter size at birth (LSB) of NZW and Boscuat rabbit does were significantly $(\mathrm{P}<0.01)$ higher than those of $\mathrm{V}$-line, while the highest value of litter weight at weaning (LWW) were recorded in V-line, followed by NZW, while the lowest one was recorded in Bouscat. The body weights and daily feed consumotion of treated rabbit does were not effected by Maca capsules, while during lacatation period were significantly increased than those of the control. The litter size at 7, 14 and 21 days of rabbit does treat with Maca capsules were significantly increased, while those at LSB and LSW were insignificantly increased compared with control group. No significant effect on milk production and litter weight at birth, 7, 14, 21 and 28 days in the treated group compared with control. There were no significant effects due to the interaction between rabbit breed and Maca treatment on the body weights, daily feed consumption, litter size, litter weight and milk production. From these findings could be concluded that the administration $\mathrm{M}$ aca capsules to rabbit doe increased the litter size at 7,14 and 21 days, while LSB, LSW, milk production and litter weight at birth, 7, 14, 21 and 28 days were not influenced.

Keywords: Rabbit does, Maca, productive performance and milk yield.

\section{INTRODUCTION}

The Maca (Lepidium meyenii) plant was mentioned as a "lost crop of the Incas" (NRC, 1989) has been cultivated and used for food and medical properties and to enhance fertility in humans and animals (Canales et al., 2000 ;Dini et al., 1994 ;Quiroz et al., 1997 and Cobo, 1956).

The findings of Ruiz-Luna et al. (2005) showed that that offspring number for mice females administered with Maca were significantly $(\mathrm{P}<0.05)$ increased compared with control group. Similarly, Chacon (1997) reported Maca increased the number of follicles for female mice than that of the control. 


\section{El-Sheikh et al.}

The results of Yoshida et al. (2017) indicated that the Maca play an important role to promotes optimal functioning for both hypothalamus and pituitary, throughout the balance effects on FSH, estradiol and progesterone of women.

Ruiz- Luna et al. (2005) reported that, female mice that received Maca delivered more pups than the control group. This suggests that Maca may have a protective effect on the number of resorptions, having a less occurrence of them between day 7 of pregnancy and the subsequent days of pregnancy in the Maca treated group. Supplementation of Maca in diets improved growth rates and survival of rainbow trout Oncorhynchus mykiss (Walbaum) alevins and juveniles (Lee et al., 2004).

Clark et al. (1994) reported that, some possible mechanisms through which Maca may act include increased uterine receptivity, altered immune functions and effects on vascular system. It is known that functional lymphocytic progesterone binding sites are needed for the maintenance of normal pregnancy, and that progesterone-mediated immune suppression is needed for the maintenance of gestation. (Szekeres et al., 1994).

Amstislavsky et al. (2004) said that litter size was higher at birth and at postnatal day 4 in the groups treated with Maca than in the controls. This effect seems to be due to a reduction in embryo resorptions, since number of implantation sites were similar in mice treated with Maca than in control. This effect seems not to be due to any estrogenic activity of Maca, since exposure to estradiol-17 beta or the proestrogen methoxychlor reduced litter size.

Finally, using the Maca plant was restricted to humans and mice based on the research obtained. There were rare of literatures on Maca effect on the rabbit, therefore, the current study was conducted to evaluate the impact of treating rabbit does with Maca in capsulated form during the experimental period (56 days) on the productive traits of rabbits.

\section{MATERIALS AND METHODS}

This study was carried out at the research rabbit farm, Poultry Production Department, Faculty of Agriculture Sohag University from August 2017 to January 2018. It was to investigate the effect of Maca on the productive and reproductive performance of rabbit does.

\section{Experimental design:}

A total of 36 rabbit does V-line, New Zealand white and Bouscat, with 12 of each. Rabbits were divided equally into two equal groups; each of them included $6 \mathrm{~V}$-line, 6 Newzeland and 6 Bouscat and with 12 of each. Rabbits were divided equally into two equal groups; each of them included 6 V-line , 6 Newzeland and 6 Bouscat. In the $1^{\text {st }}$ group, rabbits were fed a commercial breeder ration without any supplementation, while the $2^{\text {nd }}$ group were fed the commercial breeder ration and orally administered with $500 \mathrm{mg}$ Maca capsules/doe/day for one week before mating. All does were re-administered with the same dose after three days from parturition for one week (day per day), then re-mated directly for the second and third parties.

\section{Housing the experimental rabbits:}

All does were individually housed in wire galvanized battery cages $(50 \mathrm{~cm} \mathrm{~L} \times 50 \mathrm{~cm} \mathrm{~W} \times 40 \mathrm{~cm} \mathrm{H})$ in open side house under the same managerial and hygienic conditions. They were daily exposed to 12 continuous lighting hours as well as they were offered ad-libitum the feed and fresh tap water during the experimental period.

\section{Experimental diets:}

All experimental rabbit does were fed on a basal commercial. Basal diet was formulated to meet all nutrients requirements according to NRC (1989) and was nearly iso-nitrogenous and iso-caloric based on digestible energy and crude protein and was fortified with adequate vitamins and minerals mixtures. The basal diet included $16.89 \%$ crude protein, $12.67 \%$ crude fiber, $2.99 \%$ fat, $0.63 \% \mathrm{Ca}$ and $2799 \mathrm{Kcal} / \mathrm{kg}$ digestible energy. Analytical composition of dry Maca composition included $10.2 \%$ crude protein, 59.0\% carbohydrates, $2.20 \%$ fat, and 8.5\% fibers (Documenta Geigy., 1963).

\section{Climatic conditions:}

The interior ambient temperature $\left({ }^{\circ} \mathrm{C}\right)$ and relative humidity $(\%)$ were daily recorded in the rabbit farm at 9 am and 13 pm by using a thermo-hygrometer. The temperature humidity index was calculated and recorded by the following equation according to Marai et al., (2002): 
$\mathrm{THI}=\mathrm{db}^{\circ} \mathrm{C}-\left[(0.31-0.31 \mathrm{RH} / 100) \times\left(\mathrm{db}^{\circ} \mathrm{c}-14.4\right)\right]$

$\mathrm{THI}=$ Temperature humidity index, $\mathrm{db}^{\circ} \mathrm{C}=$ the ambient temperature, $\mathrm{RH}=$ the relative humidity $(\%)$.

Table (1): Average of ambient temparature, relative humidity and temperature humidity index during the experimental period.

\begin{tabular}{lcccc}
\hline Period & Date & AT $\left({ }^{\circ} \mathrm{C}\right)$ & RH $(\%)$ & THI (units) \\
\hline 1 & 15 Aug.-12 Sep. & 30.86 & 63.25 & 22.53 \\
2 & 12 Sep.-10 Oct. & 29.18 & 61.75 & 21.77 \\
3 & 10 Oct.-7 Nov. & 28.92 & 61.75 & 21.64 \\
4 & 7 Nov.-5 Dec. & 25.63 & 57.50 & 20.15 \\
5 & 5 Dec. -2 Jan. & 22.00 & 58.25 & 18.27 \\
6 & 2 Jan.- 30 Jan. & 18.63 & 58.25 & 16.55 \\
\hline
\end{tabular}

$\overline{A T}=$ Ambient temperature $\left(A T /{ }^{\circ} \mathrm{C}\right), \mathrm{RH}(\%)=$ Relative humidity $\left(A T{ }^{\circ} \mathrm{C}\right), \mathrm{THI}$ (index) $=$ Temperature humidity index , Period $=28$ days.

\section{Lighting program:}

All rabbits exposed to the same lighting program according the natural day length. According the data in Table (2) which shows the length of every day during the experimental period, so the design light programe curve was as follow:

The lighting program is continuous light and dark cycles and is decreasing lighting programe. The light intensity was 5 Lux during the day light.

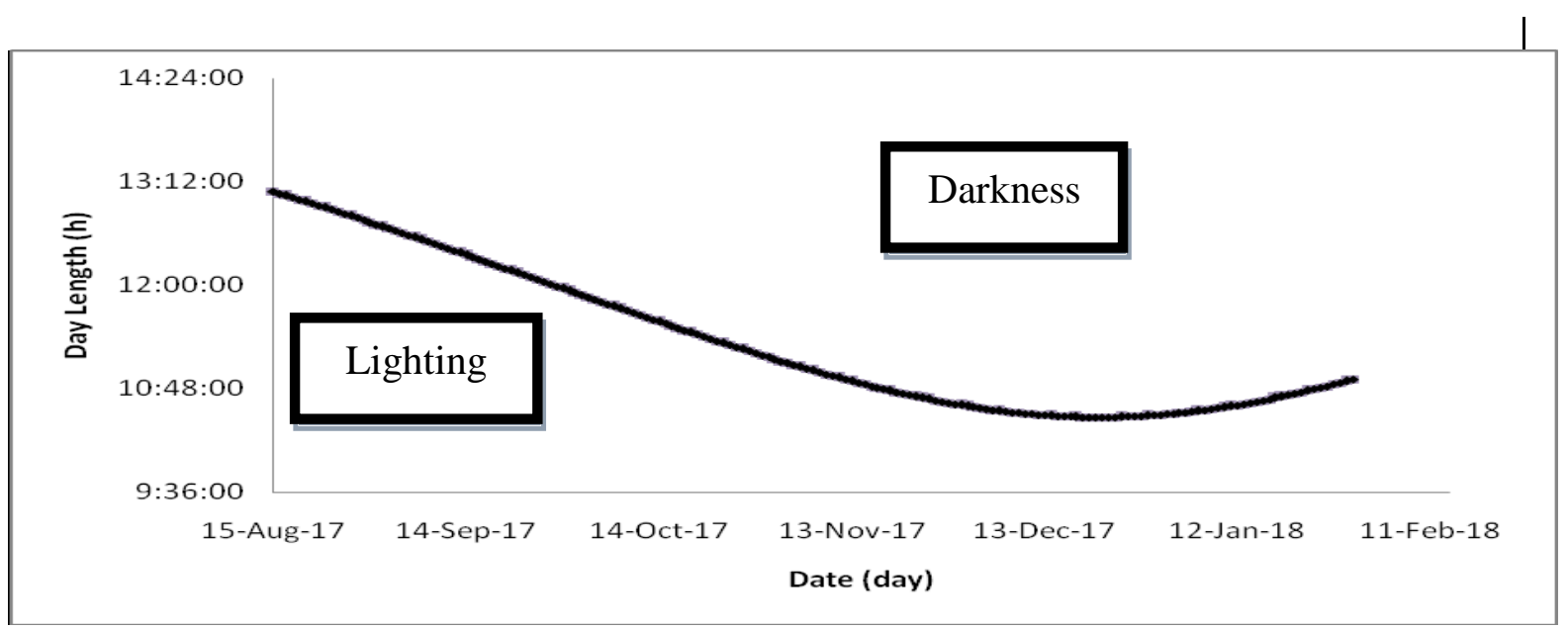

\section{Studied traits:}

Body weights $(\mathrm{g})$ : rabbit does were weighed at the beginning, after dosage, one week from matting and at parturition, while the changing body weight for each rabbit doe was calculated during the experimental period i.e. from administration up to the weaning. The daily feed intake (g) for rabbit does were weighed and weekly recorded during the period of administration, pregnancy and lactation periods.

Litter size (kids), the number of kids were counted and recorded at birth, 7, 14, 21 and 28 days (weaning), while the kids were weighed (LW/g) at birth, 7, 14, 21 and 28 days (weaning).

Pre-weaning mortality rate (PWMR/\%): Pre weaning mortality rate of progenies was recorded from birth up to weaning (28 day). Daily milk production (g) was estimated and recoded two times weekly during the $1^{\text {st }}, 2^{\text {nd }}, 3^{\text {rd }}$, and $4^{\text {th }}$ weeks, respectively of the lactation period by using the weight-suckleweight technique (removing the born kids from their dams at 12 hours before suckling), according to McNitt and Lukefahr (1990), while the total milk yield (TMY/g) was estimated as the sum of milk production during the $1^{\text {st }}, 2^{\text {nd }}, 3^{\text {rd }}$ and $4^{\text {th }}$ weeks of lactation period, respectively.

\section{Statistical analysis:}




\section{El-Sheikh et al.}

The obtained data were statistically analyzed using GLM, procedure (SAS, 2004). Duncan's new multiple ranges tests (Duncan, 1955) were used to determine significant differences between treatment means. The following linear model was applied: $E i j=\mu+B_{i}+T_{j}+B_{i} T_{j}+e_{i j}$

Where, Yij= Observation measured, $\mu=$ Overall mean, $B_{i}=$ Effect of rabbit breed $(1,2$ and 3),

$\mathrm{Tj}=$ Effect of Maca treatment $(\mathrm{j}=1$ and 2$), \mathrm{BT}_{\mathrm{ij}}=$ Interaction between rabbit breed and Maca treatment, Eij= Random error component was normally distributed assumed.

\section{RESULTS AND DISCUSSION}

\section{Effect of treatments on the body weight of rabbit does:}

The results in Table 2 showed that the body weights of V-line and NZW rabbit does after treating and birth were significantly $(\mathrm{P} \leq 0.01)$ lower than the Bouscat does. The increased body weight of Bouscat could be attributed to the genetical effect, which positively reflects the variations in body weight and their behavior of different rabbit lines. These findings disagreed with Steven et al., (1983), who found that the NZW rabbit does were significantly heavier than that of the California rabbit does at 154 days during the first breeding season. Similarly, the findings of Iraqi et al., (2010), found that the body weight for V-Line rabbit does were superior to Gabali rabbit does.

The results showed that body weights of rabbit does in the control group were insignificantly improved as compared to treatment group. These results are in agreement with those of Ruiz-Luna et al., (2005), who found that the body weights of female mice orally treated with $1 \mathrm{~g}$ Yellow Maca $/ \mathrm{kg} \mathrm{BW}$ were insignificantly influenced than those of females in the control group. Similarly, Manuel Gasco et al., (2008) found the body weights of rats treated with Maca during the experiment (28 days) were remarkably increased than those of the control group. In contrast, these results disagreed with those of EL-Tohamy et al. (2012), who found that the final body weight of male NZW rabbits supplemented with $9 \%$ for radish, rocket, black cumin and mixed meals diet $(3 \%$ radish $+3 \%$ rocket $+3 \%$ black cumin) were significantly decreased than those of the control group.

The results showed that there were no significant differences in the body weight for rabbit does at different periods due to the interaction between rabbit breed and Maca treatment allover experimental period.

Table (2): Body weight of rabbit does affect by breed, Maca treatment and their interaction $(\mathrm{LSM} \pm \mathrm{SE})$.

\begin{tabular}{|c|c|c|c|c|}
\hline \multirow{2}{*}{\multicolumn{2}{|c|}{ Breed / Treatment }} & DWBT $(g) /$ Initial $)$ & DWAT $(\mathrm{g})$ & DWAB $(\mathrm{g})$ (Finial) \\
\hline & & \multicolumn{3}{|c|}{ Effect of rabbit breed (B) } \\
\hline & V-line & $2409.50 \pm 65.7$ & $2432.50^{\mathrm{b}} \pm 50.5$ & $2633.64^{\mathrm{b}} \pm 45.7$ \\
\hline & NZW & $2488.24 \pm 63.7$ & $2552.85^{\mathrm{b}} \pm 49.8$ & $2702.42^{\mathrm{b}} \pm 49.6$ \\
\hline & Bouscat & $2565.46 \pm 63.8$ & $2721.75^{\mathrm{a}} \pm 50.0$ & $2871.61^{\mathrm{a}} \pm 50.7$ \\
\hline \multicolumn{5}{|c|}{ Effect of Maca treatment $(\mathrm{T})$} \\
\hline & Control & $2438.81 \pm 52.1$ & $2585.57 \pm 41.7$ & $2701.11 \pm 38.7$ \\
\hline & Treatment & $2536.68 \pm 53.1$ & $2552.50 \pm 40.1$ & $2770.68 \pm 40.8$ \\
\hline \multicolumn{5}{|c|}{ Effect of interaction $(\mathrm{B} \times \mathrm{T})$} \\
\hline \multirow{2}{*}{ V-line } & Control & $2412.81 \pm 92.9$ & $2437.50 \pm 71.5$ & $2646.92 \pm 65.9$ \\
\hline & Treatment & $2406.25 \pm 92.9$ & $2427.50 \pm 71.5$ & $2620.36 \pm 63.5$ \\
\hline \multirow{2}{*}{ NZW } & Control & $2472.06 \pm 90.1$ & $2503.82 \pm 69.3$ & $2613.18 \pm 71.6$ \\
\hline & Treatment & $2504.41 \pm 90.1$ & $2601.88 \pm 71.5$ & $2791.67 \pm 68.5$ \\
\hline \multirow{2}{*}{ Bouscat } & Control & $2431.55 \pm 87.6$ & $2716.17 \pm 67.4$ & $2843.21 \pm 63.5$ \\
\hline & Treatment & $2699.375 \pm 92.9$ & $2727.33 \pm 73.8$ & $2900.00 \pm 79.1$ \\
\hline \multicolumn{5}{|l|}{ Probability } \\
\hline & Treatment (T) & 0.1914 & 0.5690 & 0.2205 \\
\hline & raction $(\mathrm{B} \times \mathrm{T})$ & 0.2683 & 0.7215 & 0.3197 \\
\hline
\end{tabular}

${ }_{A, b}$ Means with different letters within each column are significantly different $(P \leq 0.05)$.

Sig = Significant, $N s=$ Non-significant, $C=$ Control group, $T=$ Treatment group 


\section{Effect of treatments on the feed consumption of rabbit does:}

The results in Table 3 showed that the daily feed consumption for NZW rabbits does during the preparation period were significantly $(\mathrm{P} \leq 0.01)$ increased as compared with Bouscat and $\mathrm{V}$-line rabbit does. While the means of feed consumption for V-line and NZW rabbit does during lactation period were significantly increased than those of the Bouscat rabbit does. The means of feed consumption of rabbit does during supplementation and pregnancy periods were not affected. Generally, the means of daily and total feed consumption were not affected by rabbit breed. The increased feed consumption for V-line and NZW rabbit does could be attributed to increased number of kids especially during 21 to 28 days of the lactation period. These results agreed with Steven et al., (1983), who found that the daily feed consumption for NZW rabbit were significantly $(\mathrm{P}<0.01)$ increased than those of the Californian does.

The results in table 3 indicated that the daily feed consumption of rabbit does treated with Maca capsule during preparation, supplementation and pergnancy periods were not effected, while during lacatation period was significantly increased than those of the control. Generally, from these findings could be noted that the means of daily and total feed intake for treated rabbit does were insignificantly increased than those of the control group. The increased feed consumption for treated rabbit does during lacatation period could be attributed to an increased number of rabbit kids especially from birth up to 21 days of age than those of the control. These results agreed with EL-Tohamy et al. (2012), who found that the best feed conversion values were recorded for NZW rabbits supplemented with $9 \%$ radish, $9 \%$ rocket, mixed meals diet ( $3 \%$ radish $+3 \%$ rocket $+3 \%$ black cumin) as compared with control group. Also, the results of Leung and Foster (1996) reported that the improved feed conversion values could be attributed to the properties of these materials that act as antibacterial, antiprotozoal, antifungal and antioxidant. Also, the results of Nguyen and Nguyen (2008) showed that the better feed consumption and feed conversion ratio of crude protein for rabbits supplemented with diets contained 60 and $80 \%$ cabbage than those of the control.

The results in table 3 showed no significance in the feed consumption for different rabbit lines during supplementation period, while during preparation, pregnancy and lactation as well as daily and total feed consumption were not affected. The increased feed consumption of rabbit does during supplementation period could be attributed to the differences in feed consumption between different lines and treatment.

Table (3): Daily feed consumption of rabbit does affect by breed, Maca treatment and their interaction $(\mathrm{LSM} \pm \mathrm{SE})$.

\begin{tabular}{|c|c|c|c|c|c|c|c|}
\hline \multicolumn{2}{|c|}{ Line / Treatment } & $\begin{array}{l}\text { Preparation } \\
\text { (g) }\end{array}$ & $\begin{array}{l}\text { Supplementation } \\
(\mathrm{g})\end{array}$ & $\begin{array}{l}\text { Pregnancy } \\
\text { (g) }\end{array}$ & $\begin{array}{l}\text { Lactation } \\
\quad(\mathrm{g})\end{array}$ & $\begin{array}{l}\text { Daily } \\
\text { feed intake } \\
(\mathrm{g})\end{array}$ & $\begin{array}{l}\text { Total feed } \\
\text { intake }(\mathrm{kg})\end{array}$ \\
\hline \multicolumn{8}{|c|}{ Effect of rabbi breed (B) } \\
\hline V-line & & $122.91^{\mathrm{b}} \pm 2.9$ & $129.16 \pm 3.8$ & $144.38 \pm 6.3$ & $171.78^{\mathrm{a}} \pm 4.2$ & $134.16 \pm 4.1$ & $29.09 \pm 1.7$ \\
\hline NZW & & $144.94^{\mathrm{a}} \pm 2.9$ & $136.30 \pm 3.8$ & $134.53 \pm 6.3$ & $164.97^{\mathrm{a}} \pm 4.0$ & $134.14 \pm 4.1$ & $30.99 \pm 1.7$ \\
\hline Bouscat & & $124.29^{\mathrm{b}} \pm 2.9$ & $136.22 \pm 3.8$ & $137.61 \pm 6.3$ & $138.37^{\mathrm{b}} \pm 4.2$ & $123.41 \pm 4.1$ & $28.51 \pm 1.7$ \\
\hline \multicolumn{8}{|c|}{ Effect of Maca treatment $(\mathrm{T})$} \\
\hline Control & & $131.27 \pm 2.4$ & $135.40 \pm 3.1$ & $143.43 \pm 5.3$ & $152.26^{\mathrm{b}} \pm 3.4$ & $129.78 \pm 3.4$ & $28.71 \pm 1.4$ \\
\hline Treatmer & & $130.16 \pm 2.4$ & $132.39 \pm 3.1$ & $134.25 \pm 5.1$ & $164.84^{\mathrm{a}} \pm 3.4$ & $131.36 \pm 3.4$ & $30.34 \pm 1.4$ \\
\hline \multicolumn{8}{|c|}{ Effect of interaction $(\mathrm{B} \times \mathrm{T})$} \\
\hline \multirow{2}{*}{ V-line } & $\mathrm{C}$ & $120.37 \pm 4.1$ & $132.60 \pm 5.4$ & $152.49 \pm 9.7$ & $173.94 \pm 6.2$ & $133.90 \pm 5.8$ & $27.12 \pm 2.5$ \\
\hline & $\mathrm{T}$ & $125.46 \pm 4.1$ & $125.72 \pm 5.4$ & $136.28 \pm 8.9$ & $169.93 \pm 5.7$ & $134.42 \pm 5.8$ & $31.05 \pm 2.5$ \\
\hline \multirow{2}{*}{ NZW } & $\mathrm{C}$ & $147.37 \pm 4.1$ & $147.62 \pm 5.4$ & $136.45 \pm 8.9$ & $156.22 \pm 5.7$ & $136.59 \pm 5.8$ & $31.16 \pm 2.5$ \\
\hline & $\mathrm{T}$ & $142.52 \pm 4.1$ & $124.99 \pm 5.4$ & $132.60 \pm 8.9$ & $173.72 \pm 5.7$ & $131.68 \pm 5.8$ & $30.42 \pm 2.5$ \\
\hline \multirow{2}{*}{ Bouscat } & $\mathrm{C}$ & $126.07 \pm 4.1$ & $125.99 \pm 5.4$ & $141.34 \pm 8.9$ & $126.63 \pm 5.7$ & $118.86 \pm 5.8$ & $27.46 \pm 2.5$ \\
\hline & $\mathrm{T}$ & $122.51 \pm 4.1$ & $146.44 \pm 5.4$ & $133.87 \pm 8.9$ & $150.10 \pm 6.2$ & $127.97 \pm 5.8$ & $29.56 \pm 2.5$ \\
\hline \multicolumn{8}{|c|}{ Probability } \\
\hline & (B) & 0.0001 & 0.3302 & 0.5509 & 0.001 & 0.1213 & 0.5821 \\
\hline Trea & $(\mathrm{T})$ & 0.7457 & 0.4999 & 0.2229 & 0.0167 & 0.7426 & 0.4240 \\
\hline
\end{tabular}




\begin{tabular}{|c|c|c|c|c|c|}
\hline Interaction $(\mathrm{B} \times \mathrm{T})$ & 0.4349 & 0.0015 & 0.7871 & 0.4876 & 0.5886 \\
\hline
\end{tabular}

\section{Effect of treatments on litter size and pre-weaning mortality of rabbit Does:}

The results in Table 4 showed that the litter size at birth of NZW and Boscuat rabbit does were significantly $(\mathrm{P}<0.01)$ increased than those of $\mathrm{V}$-line. The significant increased in litter size at birth of Bouscat rabbit does could reflect the increased ovulation rate for these breeds compare with NZW and Vline. The highest values of litter size at weaning were recorded in NZW, followed by V-line, while the lowest one was recorded in Bouscat. Generally, the litter size at 7, 14 and 21 days were insignificantly affected. The increased litter size for both breeds may be attributed to decrease mortality rate, which coinsoided with increase milk production. Also, this may be attributted to animal genotype (Harris et al., 1982).These results are in agreement with those of Das et al., (2006), who found a significant $(\mathrm{P}<0.05)$ higher in litter size at weaning for NZW rabbit does than those of Soviet Chinchilla rabbit does. Similarly, the results of Azoz and El-kholy (2005), indicated that litter size at birth and at weaning of V-line rabbit does were significantly increased than those of Bouscat rabbit does. The obtained data indicated that the highest pre-weaning mortality rate was recorded in Bouscat does, followed by V-line, while the lowest one was recorded in NZW rabbit does without any significant effect. These findings agreed with Steven $e t$ al., (1983), indicated that the preweaning mortality in NZW rabbit does were significantly greater than those of Californion rabbit does. In contrast, the results of Azoz and El-Kholy (2005) reported that the number of kids at birth for V-line and Bouscat were insignificantly affected. Also, the results of ElHammady and Abdel-Kareem (2015) showed no significant differences in LSB and LSW as well as PWM among V-Line, NZW and Bouscat rabbit does.

Table (4): Litter size and pre-weaning mortality of rabbit does affected by breed, treatment and their interaction $(\mathbf{L S M} \pm \mathrm{SE})$.

\begin{tabular}{|c|c|c|c|c|c|c|c|}
\hline \multicolumn{2}{|c|}{ Breed/Treatment } & LSB (kids) & LS7days & LS14days & LS21days & LS28days & PWM $(\%)$ \\
\hline \multicolumn{8}{|c|}{ Effect of rabbit breed (B) } \\
\hline \multicolumn{2}{|c|}{ V-line } & $4.18^{\mathrm{b}} \pm 0.4$ & $3.83 \pm 0.4$ & $4.21^{\mathrm{a}} \pm 0.4$ & $3.83 \pm 0.4$ & $3.49^{\mathrm{a}} \pm 0.5$ & $44.02^{\mathrm{a}} \pm 7.7$ \\
\hline \multicolumn{2}{|l|}{ NZW } & $5.47^{\mathrm{a}} \pm 0.5$ & $4.48 \pm 0.4$ & $4.37^{\mathrm{a}} \pm 0.4$ & $4.31 \pm 0.4$ & $3.56^{\mathrm{a}} \pm 0.5$ & $35.78^{\mathrm{b}} \pm 8.9$ \\
\hline \multicolumn{2}{|c|}{ Bouscat } & $5.75^{\mathrm{a}} \pm 0.5$ & $5.19 \pm 0.5$ & $4.38^{\mathrm{a}} \pm 0.5$ & $4.65 \pm 0.6$ & $1.93^{\mathrm{b}} \pm 0.5$ & $67.40^{\mathrm{a}} \pm 8.5$ \\
\hline \multicolumn{8}{|c|}{ Effect of Maca treatment (T) } \\
\hline \multicolumn{2}{|c|}{ Control } & $4.66 \pm 0.4$ & $3.93^{\mathrm{b}} \pm 0.3$ & $3.79^{\mathrm{b}} \pm 0.3$ & $3.75^{\mathrm{b}} \pm 0.3$ & $2.87 \pm 0.4$ & $42.21 \pm 6.6$ \\
\hline \multicolumn{2}{|c|}{ Treatment } & $5.60 \pm 0.4$ & $5.07^{\mathrm{a}} \pm 0.4$ & $4.85^{\mathrm{a}} \pm 0.4$ & $4.81^{\mathrm{a}} \pm 0.4$ & $3.11 \pm 0.4$ & $55.93 \pm 7.1$ \\
\hline \multicolumn{8}{|c|}{ Effect of interaction $(\mathrm{B} \times \mathrm{T})$} \\
\hline \multirow{2}{*}{ V-line } & $\mathrm{C}$ & $4.00 \pm 0.6$ & $3.45 \pm 0.6$ & $3.27 \pm 0.5$ & $3.27 \pm 0.5$ & $3.09 \pm 0.7$ & $32.01 \pm 11.4$ \\
\hline & $\mathrm{T}$ & $4.36 \pm 0.6$ & $4.20 \pm 0.6$ & $5.14 \pm 0.6$ & $4.37 \pm 0.6$ & $3.89 \pm 0.7$ & $56.04 \pm 10.6$ \\
\hline \multirow{2}{*}{ NZW } & $\mathrm{C}$ & $5.27 \pm 0.7$ & $4.56 \pm 0.6$ & $4.33 \pm 0.6$ & $4.22 \pm 0.6$ & $3.46 \pm 0.7$ & $38.52 \pm 12.6$ \\
\hline & $\mathrm{T}$ & $5.67 \pm 0.6$ & $4.40 \pm 0.6$ & $4.40 \pm 0.5$ & $4.40 \pm 0.5$ & $3.67 \pm 0.6$ & $33.04 \pm 12.6$ \\
\hline \multirow{2}{*}{ Bouscat } & $\mathrm{C}$ & $4.71 \pm 0.6$ & $3.78 \pm 0.6$ & $3.75 \pm 0.6$ & $3.62 \pm 0.6$ & $2.07 \pm 0.6$ & $56.09 \pm 10.6$ \\
\hline & $\mathrm{T}$ & $6.78 \pm 0.7$ & $6.60 \pm 0.8$ & $5.00 \pm 0.8$ & $5.67 \pm 1.0$ & $1.78 \pm 0.7$ & $78.70 \pm 13.3$ \\
\hline \multicolumn{8}{|c|}{ Probability } \\
\hline \multicolumn{2}{|c|}{ Breed (B) } & 0.0282 & 0.1132 & 0.9499 & 0.4375 & 0.0277 & 0.0313 \\
\hline \multicolumn{2}{|c|}{ Treatment (T) } & 0.0711 & 0.0305 & 0.0402 & 0.0377 & 0.6664 & 0.1606 \\
\hline \multicolumn{2}{|c|}{$(\mathrm{B} \times \mathrm{T})$} & 0.3180 & 0.0826 & 0.2671 & 0.3708 & 0.7298 & 0.3972 \\
\hline
\end{tabular}

${ }^{A, b}$ Means with different letters within each column are significantly different $(P \leq 0.05)$.

Sig = Significant, Ns= Non-significant, $C=$ Control group, $T=$ Treatment group

The effect of Maca treatment, the obtained findings indicated that the highest value of the number of litter size at7, 14 and 21 days were recorded in Maca treated group with a significant effect. While the increasing number of litter size at birth and weaning were not significantly. They attributed to the increase of available $\mathrm{m}$ ilk production for kids, which pronouncedly decreased the mortality rate of young kids (Szendro et al., 2002). These results agree with Ruiz-Luna et al., (2005), who reported that the number of pups for female mice treated with $1 \mathrm{~g}$ Maca $/ \mathrm{kg} \mathrm{BW}$ were remarkably increased than those of the control group. They suggested that Maca 
may have a protective effect on the number of resorptions, having a less occurrence of them between day 7 of pregnancy and the subsequent days of pregnancy in the Maca treated group. Similarly, Amstislavsky et al., (2004) reported litter size at birth and at postnatal day 4 in the groups treated with Maca was higher compared with the control group. They attributed this effect to a reduction in embryo resorption since numbers of implantation sites were similar in mice treated with Maca than in controls as well as may be due to any estrogenic activity of Maca, since exposure to estradiol-17 beta or the pro-estrogen methoxychlor reduced litter size. Similarly, Manuel Gasco et al., (2008), said that the number of mice offspring was remarkably increased when Maca was administered. Referring to preweaning mortality rate, the obtained findings showed no significant effect of Maca administration on litter size of rabbits. These results agreed with those of Ruiz-Luna et al., (2005), who found that the pups mortality rate for mice treated with $1 \mathrm{~g}$ Maca $/ \mathrm{kg}$ BW were remarkably decreased by about $32.16 \%$ than those of the control group.

Effect of interaction, the results in table 4 showed that there were no significant effect due to the interaction between rabbit line and Maca treatment on litter size at birth, 7, 14, 21 and 28days as well as pre-weaning mortality rate.

\section{Effect of treatments on litter weight of rabbit:}

The results in Table (5) showed that the litter weight at birth for Boscuat rabbit were significantaly $(\mathrm{P}<0.01)$ increased, while the litter weight at 7, 14, 21 and 28 days were insignificantly effecte as compared to those of NZW and V-line. The obtained results indicated that the highest value of litter weight at weaning were recorded in V-line, followed by NZW, while the lowest one was recorded in Bouscat, could reflect the decreased the perceent of mortality rat. Also, the increased litter weight of kids at birth for Boscuat rabbit could be attributed to increased ovulation rate and consequantly litter size at birth than those of of NZW and V-line. These results agreed with those of Khalil et al., (1987), who found that the increased litter weight of kids could be due to doe effect, which affecting on body weight at birth and up to weaning. Similarly, the results of Azoz and Kholy (2005), indicated that litter weight at weaning for V-line rabbits were insignificantly increased than those of Bouscat rabbits. In contrast, the same authors found that litter weight at birth for V-line rabbits were insignificantly increased than those of Bouscat rabbits. Similar results were also found by Das et al., (2006), who found a significant $(\mathrm{P}<0.05)$ higher litter size and litter weight at weaning in NZW rabbits than those of the Soviet Chinchilla rabbits.

The results indicated that no significant effect on the litter weight at birth, 7, 21 and 28 days, while at 14 days was insignificantly lower than the control group. These results agreed with Ruiz-Luna et al., (2005), who found that the litter size and weight of mice treated with Maca were remarkably increased than that of the control.

It had no significant effect due to the interaction between rabbit line and Maca treatment on litter weight at birth, 7, 14, 21 and 28 days (weaning).

Table (5): Litter weight of rabbit progenies affected by line, Maca treatment and their interaction (LSM \pm SE).

\begin{tabular}{|c|c|c|c|c|c|c|}
\hline \multicolumn{2}{|c|}{ Breed /treatment } & At birth & 7 days & 14 days & 21 days & $\begin{array}{c}28 \text { days } \\
\text { (weaning) }\end{array}$ \\
\hline \multicolumn{7}{|c|}{ Effect of rabbit breed (B) } \\
\hline V-line & & $231.67^{\mathrm{b}} \pm 20.0$ & $394.75 \pm 36.5$ & $684.01 \pm 51.3$ & $995.60 \pm 69.6$ & $1267.78 \pm 90.5$ \\
\hline NZW & & $297.03^{\mathrm{a}} \pm 21.7$ & $460.22 \pm 38.4$ & $747.82 \pm 48.7$ & $1030.42 \pm 66.1$ & $1265.94 \pm 86.0$ \\
\hline Bouscat & & $316.71^{\mathrm{a}} \pm 22.2$ & $482.56 \pm 46.6$ & $778.00 \pm 64.9$ & $972.31 \pm 97.4$ & $1199.44 \pm 124.8$ \\
\hline \multicolumn{7}{|c|}{ Effect of Maca treatment $(\mathrm{T})$} \\
\hline Control & & $265.11 \pm 16.9$ & $438.52 \pm 31.2$ & $771.85 \pm 40.4$ & $952.96 \pm 54.9$ & $1168.31 \pm 69.8$ \\
\hline Treatment & & $298.30 \pm 17.9$ & $453.17 \pm 35.2$ & $701.36 \pm 49.6$ & $1045.93 \pm 72.8$ & $1320.46 \pm 94.7$ \\
\hline \multicolumn{7}{|c|}{ Effect of interaction $(\mathrm{B} \times \mathrm{T})$} \\
\hline \multirow{2}{*}{ V-line } & $\mathrm{C}$ & $223.85 \pm 28.8$ & $370.00 \pm 50.3$ & $582.73 \pm 63.9$ & $885.91 \pm 86.8$ & $1102.27 \pm 112.8$ \\
\hline & $\mathrm{T}$ & $238.93 \pm 27.8$ & $419.50 \pm 52.8$ & $785.29 \pm 80.1$ & $1105.29 \pm 108.8$ & $1433.29 \pm 141.4$ \\
\hline \multirow{2}{*}{ NZW } & $\mathrm{C}$ & $288.64 \pm 31.3$ & $484.44 \pm 55.7$ & $801.33 \pm 70.7$ & $1073.33 \pm 95.9$ & $1263.78 \pm 124.7$ \\
\hline & $\mathrm{T}$ & $305.42 \pm 30.0$ & $436.00 \pm 52.8$ & $694.30 \pm 67.0$ & $987.50 \pm 91.0$ & $1268.10 \pm 118.3$ \\
\hline \multirow{2}{*}{ Bouscat } & $\mathrm{C}$ & $282.86 \pm 27.8$ & $461.11 \pm 55.7$ & $931.50 \pm 74.9$ & $899.63 \pm 101.8$ & $1138.89 \pm 124.7$ \\
\hline & $\mathrm{T}$ & $350.56 \pm 34.6$ & $504.00 \pm 74.7$ & $624.50 \pm 106.0$ & $1045.00 \pm 166.2$ & $1260.00 \pm 216.1$ \\
\hline \multicolumn{7}{|l|}{ Probability } \\
\hline Breed (B) & & 0.0123 & 0.2751 & 0.4821 & 0.8706 & 0.8900 \\
\hline Treatment (T) & & 0.1812 & 0.7567 & 0.2767 & 0.3138 & 0.2028 \\
\hline
\end{tabular}




\begin{tabular}{|c|c|c|c|}
\hline$(\mathrm{B} \times \mathrm{T})$ & 0.6245 & 0.6112 & 0.2722 \\
\hline
\end{tabular}

\section{Effect of treatment on the milk production of rabbit does:}

The results in table 6 showed that there was no significant effect observed between three rabbit lines in milk yield at $1^{\text {st }}, 2^{\text {nd }}, 3^{\text {rd }}, 4^{\text {th }}$ weeks as well as daily and total milk production. The obtained results indicated that milk yield for rabbit does during the $1^{\text {st }} 2^{\text {nd }}, 3^{\text {rd }}, 4^{\text {th }} \mathrm{wk}$ as well as daily and total milk production, were insignificantly affected by rabbit line. The insignificant variation in milk yield of rabbit doe may be due to breed effects (Cowie 1969). In contrast, the results of Mehaia et al., (2002), found that V-line had significantly increased in milk yield compared to Gabali Saudi rabbits. Also, Lebas et al., (1997) and Rommers et al., (1999) attributed the improve milk production to in $\mathrm{V}$-line does to the ability to produce higher progenies at birth and weaning.

The results indicated that there was no significant effect on milk production of treated rabbit does. Generally, the milk yield of rabbit does were remarkably decreased during the experimental period, which may be due to increased litter size at weaning. The increase of milk production in Maca treatment group reflect the increased of the number litter size in Maca treated group, seemed to stimulate the mammary glands to produce the highest quantity of milk (El-Sayaid, 1994). Morevor increased suckling intensity in large litters may allow the more complete evacuation of remainder milk, through greater oxytocin release due to increased afferent nerve stimulation of the teats (Linzell et al., 1972). Rasambainarivo et al., (2002) found that the cow supplemented with radish at 10-15 $\mathrm{kg}$ of cultivated fresh fodder radish/cow per day insignificantly affected compared with the concentrates. They calculated that the rate of decline in milk production was higher for cows fed the concentrates than for those on fodder radish. Assuming that the curves have the same origin the milk production from the radish group was $6 \%$ higher than for the cows receiving only concentrates.

It had no significant effect due to the interaction between breed and treatment on the milk production at $1^{\text {st }}$, $2^{\text {nd }}, 3^{\text {rd }}, 4^{\text {th }} \mathrm{wk}$, daily and total milk production.

Table (6): Milk production of rabbit does affect by breed, treatment and their interaction $(\mathbf{L S M} \pm \mathbf{S E})$.

\begin{tabular}{|c|c|c|c|c|c|c|c|}
\hline \multirow{2}{*}{\multicolumn{2}{|c|}{ Breed/Treatment }} & \multicolumn{4}{|c|}{ Milk production per week } & \multirow{2}{*}{ DMP } & \multirow{2}{*}{ TMP } \\
\hline & & $1^{\text {st }}$ & $2^{\text {nd }}$ & $3^{\text {rd }}$ & $4^{\text {th }}$ & & \\
\hline \multicolumn{8}{|c|}{ Effect of rabbit breed (B) } \\
\hline \multicolumn{2}{|c|}{ V-line } & $40.36 \pm 6.5$ & $67.99 \pm 7.3$ & $71.85 \pm 10.4$ & $68.35 \pm 7.9$ & $51.97 \pm 6.0$ & $1455.02 \pm 170.1$ \\
\hline \multicolumn{2}{|l|}{ NZW } & $60.33 \pm 7.1$ & $60.45 \pm 6.9$ & $74.25 \pm 9.9$ & $58.27 \pm 7.5$ & $63.94 \pm 6.6$ & $1679.80 \pm 186.5$ \\
\hline \multicolumn{2}{|l|}{ Bouscat } & $41.49 \pm 9.5$ & $72.50 \pm 10.2$ & $70.16 \pm 14.6$ & $65.89 \pm 11.1$ & $57.19 \pm 8.8$ & $1601.35 \pm 249.5$ \\
\hline \multicolumn{8}{|c|}{ Effect of Maca treatment $(\mathrm{T})$} \\
\hline \multicolumn{2}{|l|}{ Control } & $53.73 \pm 5.7$ & $65.94 \pm 5.8$ & $71.85 \pm 10.4$ & $62.82 \pm 6.2$ & $61.96 \pm 5.3$ & $1735.56 \pm 151.4$ \\
\hline \multicolumn{2}{|c|}{ Treatment } & $41.05 \pm 6.9$ & $68.02 \pm 7.7$ & $74.25 \pm 9.9$ & $65.52 \pm 8.3$ & $53.41 \pm 6.4$ & $1421.88 \pm 181.9$ \\
\hline \multicolumn{8}{|c|}{ Effect of interaction $(\mathrm{B} \times \mathrm{T})$} \\
\hline \multirow[t]{2}{*}{ V-line } & $\mathrm{C}$ & $44.81 \pm 8.7$ & $66.41 \pm 9.1$ & $79.77 \pm 13.0$ & $65.63 \pm 9.9$ & $56.44 \pm 8.1$ & $1580.33 \pm 230.3$ \\
\hline & $\mathrm{T}$ & $35.91 \pm 9.5$ & $69.57 \pm 11.4$ & $63.93 \pm 16.3$ & $71.07 \pm 12.4$ & $47.49 \pm 8.8$ & $1329.70 \pm 250.3$ \\
\hline \multirow[t]{2}{*}{ NZW } & $\mathrm{C}$ & $73.61 \pm 10.5$ & $61.40 \pm 10.1$ & $90.00 \pm 14.4$ & $64.39 \pm 10.9$ & $71.31 \pm 9.8$ & $1996.60 \pm 276.7$ \\
\hline & $\mathrm{T}$ & $47.05 \pm 9.5$ & $59.500 \pm 9.6$ & $58.50 \pm 13.7$ & $52.15 \pm 10.3$ & $56.57 \pm 8.8$ & $1363.00 \pm 250.3$ \\
\hline \multirow[t]{2}{*}{ Bouscat } & $\mathrm{C}$ & $42.78 \pm 10 . .5$ & $70.00 \pm 10.7$ & $68.49 \pm 15.3$ & $58.44 \pm 11.6$ & $58.21 \pm 9.8$ & $1629.76 \pm 276.7$ \\
\hline & $\mathrm{T}$ & $40.21 \pm 15.7$ & $75.00 \pm 17.4$ & $71.83 \pm 24.9$ & $73.33 \pm 18.9$ & $56.18 \pm 14.7$ & $1572.94 \pm 415.1$ \\
\hline \multicolumn{8}{|c|}{ Probability } \\
\hline \multicolumn{2}{|c|}{ Breed (B) } & 0.0959 & 0.5774 & 0.9702 & 0.6384 & 0.4118 & 0.6665 \\
\hline \multicolumn{2}{|c|}{ Treatment $(\mathrm{T})$} & 0.1638 & 0.8283 & 0.2897 & 0.7956 & 0.3095 & 0.1908 \\
\hline \multicolumn{2}{|c|}{$(\mathrm{B} \times \mathrm{T})$} & 0.5238 & 0.9504 & 0.6088 & 0.5442 & 0.8441 & 0.6070 \\
\hline
\end{tabular}




\section{CONCLUSION}

In conclusion, the results of this study supported the body weights of V-line and NZW rabbit does after treating and birth were significantly $(\mathrm{P} \leq 0.01)$ lower than that of the Bouscat, while the means of daily and total feed consumption were not affected by rabbit breed. The litter size at birth (LSB) of NZW and Boscuat rabbit does were significantly $(\mathrm{P}>0.01)$ higher than those of $\mathrm{V}$-line, while the highest value of litter weight at weaning (LWW) were recorded in $\mathrm{V}$-line, followed by $\mathrm{NZW}$, while the lowest one was recorded in Bouscat.

Maca capsule had no effect on the body weights and daily feed consumotion of treated rabbit does, while during lacatation period were significantly increased than those of the control. The litter size at 7,14 and 21 days of rabbit does were significantly increased while LSB and LSW were insignificantly increased compared with control group. No significant effect of Maca on milk production and litter weight at birth, 7, 14, 21 and 28 days were not significant influenced than that of the control.

The interaction between rabbit breed and Maca treatment had no significant effect on the body weights, daily feed consumption, the litter size, the litter weight at 7,14,21 and 28 days and milk production

\section{REFERENCES}

Amstislavsky, S.Y., Kizilova, E.A., Golubitsa, A.N., Vasilkova, A.A., Eroschenko, V.P. (2004) Preimplantation exposures of murine embryos to estradiol or methoxychlor change postnatal development. Reprod Toxicol, 18:103-108.

Azoz, A.A. and El-kholy, K.H. (2005). Blood metabolites and hormones of V-line and Bouscat female rabbits under Middle Egypt conditions. Egyption J. Rabbit Sci., 15: 131-142.

Canales M, Aguilar J, Prada A, Marcelo A, Huaman C, Carbajal (2000). L. Nutritional evaluation of Lepidium meyenii (MACA) in albino mice and their descendants (in Spanish) Arch Latinoam Nutr., 50:126-33. [PubMed].

Chacón de Popovici, G (1997). La importancia de Lepidium peruvianum ("Maca") en la alimentacion y salud del ser humano y animal 2,000 anos antes y desputes del Cristo y en el siglo XXI. Lima : Servivios Gráficos " ROMERO"

Clark DA, Quarrington C, Banwatt D, Manuel J, Fupop G. (1994). Spontaneous abortion in immunodeficient SCID mice. Am J Reprod Immunol 1994, 32:15-25.

Cobo B. (1956). History of the New World, Biblioteca de Autores Espãnoles, Madrid, Spain.

Cowie A.T. (1969) Variations in the yield and composition of the milk during lactation in the rabbit and the galactopoietic effect of prolactin. J. Endocrinol., 44,437-450.

Das S.K, Das .A and Bujarbarua K.M, (2006) Productive performances, reproductive performances, and carcass traits of broiler rabbit in different generation under agro climatic condition of Meghalaya. Indian Journal of Animal Research 40 (1): 38 - 41.

Dini A, Migliuolo G, Rastrelli L, Saturnine P, Schettino O. (1994). Chemical composition of Lepidium meyenii. Food Chem. 49: 347-9.

Documenta Geigy (1963). Tables Scientifiques $16^{\text {th }}$ ed. Dep. Pharmaceutique Basel, Switzerland, PP. $515-20$.

Duncan, D. B. (1955). Multiple Ranges and Multiple F-Test. Biometrics, 11: 1- 42.

El-Sayaid, G.A. (1994). A study on milk production of New Zealand White and Californian rabbits under Egyption conditions. Egyption J. Rabbit Sci., 4:47-59.

El-Hammady H.Y. and Abdel-Kareem A. A. A. (2015). Productive performance of rabbit does producing low number of weaning kids treated with some dried herbal seeds. Egypt. Poult. Sci. 35:609-625

El-Sayaid, G.A. (1994). A study on milk production of New Zealand White and Californian rabbits under Egyption conditions. Egyption J. Rabbit Sci., 4:47-59. 


\section{El-Sheikh et al.}

El-Tohamy, M. M.; El-nattat W. S. and El-kady, R. I. (2010). The Beneficial Effects of Nigella sativa, Raphanus sativus and Eruca sativa Seed Cakes to Improve Male Rabbit Fertility, Immunity and Production. Journ.of Am. Sci.6(10):1247- 1255.

Harris, D. J. ; Harper, A.E.; Cheek, P. R. and Patton, N. M. (1982). Effect of early nest box removal on growth and mortality of young rabbits. Apreliminary report. J. Appl. Rabbit Res., 5: 133-134. .

Iraqi, M.M, Garcia M.L., Khalil, Baselga M. (2010). Evaluation of milk yield and some related maternal traits in a crossbreeding project of Egyptian Gabali breed with Spanish V-line in rabbits. J. Anim. Breed. Genet. ISSn 0931-2668.

Khalil M. H., Afifi E. A., Owen J.B. (1987). A genetic analysis of body weight traits in young Bouscat and Giza White rabbits. Anim. Prod., 45, 135- 144.

Lebas, F.; Coudert, P. ; Rochambeau, H. De.; and Thébaut, R. G. (1997). The Rabbit Husbandry, Health and Production. Food and Agriculture Organization of United Nations, FAO, Rome, Italy.

Lee K-J, Dabrowski K, Rinchard J, Gomez C, Guz L, Vilchez C. (2004). Supplementation of Maca (Lepidium meyenii) tuber meal in diets improves growth rate and survival of rainbow trout Oncorhynchus mykiss (Walbaum) alevins and juveniles. Aquac Res. 35:215-223.

Leung, A.Y.; and S. Foster (1996). Drugs and cosmetics, $2{ }^{\text {nd }}$ Encyclopedia of common Natural ingredients used in food New York: john wiley \& sons, Inc.

Linzell, J.L.; Peaker, M. and Taylor, J.C.(1972). The effects of prolactin and oxytocin on milk secretion and no the permeability of the mammary epithelium, in the rabbit. J. Physiol., 253:547.

Manuel Gasco, Sandra Yucra, Julio Rubio, and Gustavo F Gonzales (2008). “ Lepidium meyenii (Maca) Did Not Alter Female Reproductive Parameters in Adult Intact Rats" . article in journal of Complementary and integrative Medicine. January 2008.

Marai, I. F. M.; Habeeb, A. A.M. and Gad, A.E., (2002). Rabbits productive, reproductive and physiological performance traits as affected by heat stress: a review. Livest. Prod. Sci. 78, 71-90.

Mcnitt J.I., Lukefahr S.D. (1990). Effects of breed, Parity, day of lactation and number of kits on milk production of rabbits. J. Anim. Sci., 68, 1505-1512.

Mehaia, M. A. ; Khalil, M.H.; Al-Homidan, H.A. and Al-Sobayil, K. (2002). Milk yield and component to litter-gain conversion ratio in crossing of Saudi Gabali rabbits with V-line. $3^{\text {rd }}$ Scientific Conference on Rabbit Production in Hot Climates, Hurghada Egypt, 139-150.

Nguyen Thi Kim Dong and Nguyen Thanh Van, (2008). Effect of different levels of cabbage waste (Brassica olerea) replacement in paragrass (Brachiaria mutica) basal diet on growv performance and nutrient digestibility of crossbred rabbits in Mekong Delta if Vietnam. M.Sc. thesis submitted to Department of Animal Husbandry, College of Agriculture and Applied Biology, Catho University, Vietnam.

NRC (1989).National Research Council. Lost crops of the incas:I-known plants of the Andes with promise for worldwide cultivation. National Academy Press, Washing Dc.

Quiroz C. and Aliaga R. (1997). "Maca (Lepidium meyenii Walp.)," in Andean Roots and Tubers: Ahipa, Arracacha, Maca and Yacon. Promoting the Conservation and Use of Underutilized Neglected Crops, M. Hermann and J. Hellers, Eds., vol. 21, pp. 173-197, International Plant Genetic Resources Institute, Rome, Italy.

Rasambainarivo J. H, Razafindraibe H.,Rabehanitriniony M., R asoloarison R., Rafalimanantsoa E., Barson M.R.R , Fofifa- Drzv, Antananarivo and Barsona (2002). Responses to dry season supplementation by dairy cows on the highly and zones of Madagascar. Field evolution of animal feed supplementation packages, 61.

Rommers, J.M.; Kemp, B.; Meijerhof, R.; and Noorduizen, J. P. T. M. (1999). Rearinf management of rabbit does: A review. World Rabbit Sci., 7:125-138.

Ruiz- Luna, A.C., Sandra, S.,Aspajo, N.J.Rubio, J., Gasco, M., and Gonzales, G.F. (2005). Lepidium meyenii (Maca) increases litter size in normal adult female mice. Reprod.Biol Endocrinol 5-3-2005; 3(1):16. View abstract.

Steven Lukefahe' Hohenboken W.D., Cheeke P.R. and Patton N.M. (1983). Journal of Animal Science, Vol. 57, No. 5. 
Szekeres-Bartho J, Chaouat G, Kinsky R. (1990): A Progesterone-induced blocking factor corrects high resorption rates in mice treated with antiprogesterone. Am J Obstet Gynecol 163:1320-1322.

Szendro, E.; Gyovia, M.; Biro-Nemeth, E.; Radnai, I.; Matics, Zs.; Nagy, I. and Szendro, Zs. (2002). Effect of birth weight, milk supply status and feeding system on the mortality of suckling and growing rabbits. $3^{\text {rd }}$ Sci. Conf. Rabbit Prod. In Hot Climates, 8-11 October, 2002, Hurghada, Egypt, pp.401407.

Yoshida K, Ohta Y, Kawate N, Takahashi M, Inaba T. (2017). Long-term feeding of hydroalcoholic extract powder of Lepidium meyenii (Maca) enhances the steroidogenic ability of Leydig cells to alleviate its decline with ageing in male rats. Andrologia.

تاثير تجريع كبسولات الماكا على الاداء الانتاجى لامهات الارانب وعدد الخلفات وانتاج اللبن

طلعت مصطفى الثيخ1 ، احمد عبد الكريم ابوغابة1 ، كوثر عبد الرحمن غالى²، ماريان خيرى وديع3

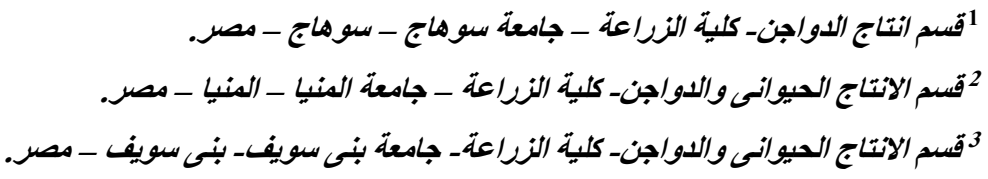

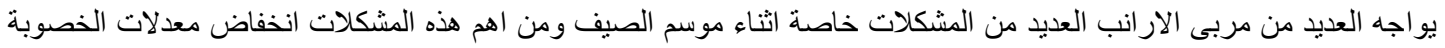

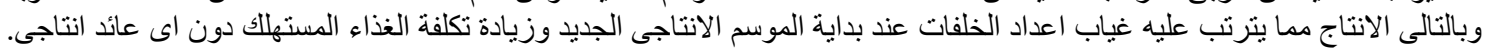

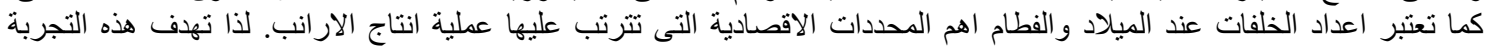

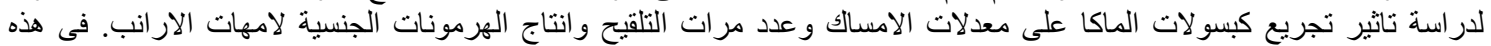

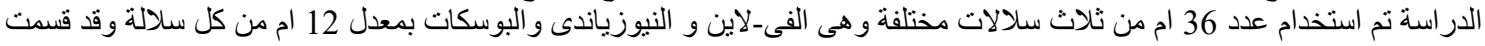

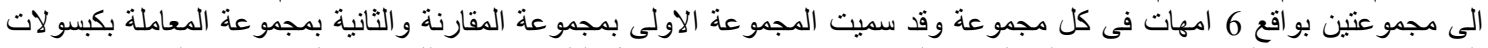

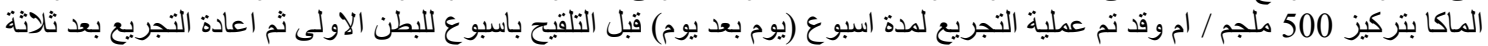

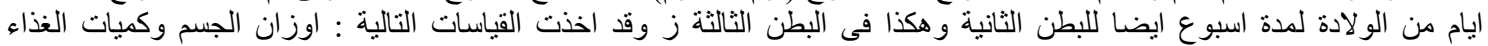
المستهكة لامهات الارانب - اعداد واوزان الخلفات عند الميلاد و عند عمر اسبوع ول14 يوم و 21 يوم وعند الفطام وكذللك كميات اللبن

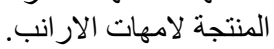

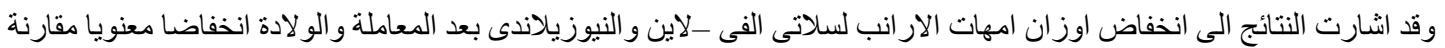

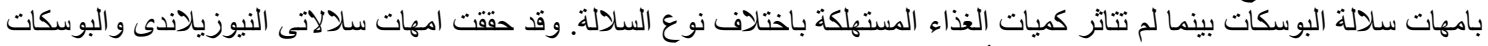

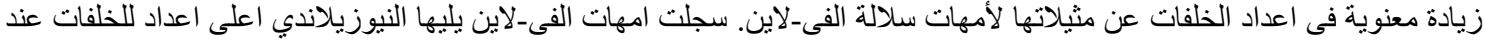
الفطام بينما سجلت امهات البوسكات اقل الاعداد التاديات

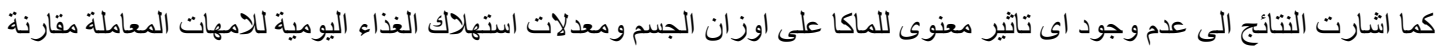

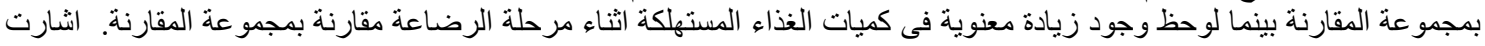

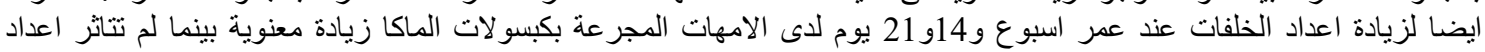

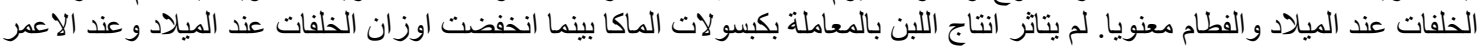
الاتية 74 و 14 و 21 28 يوم انخفاض غيل لمنير معنوى مقارنة بمجمو عة الكنترول.

اما بالنسبة لناثير التداخل بين نوع السلالة والمعاملة بكبسو لات الماكا لم يلاحظ إى تاثير معنوى على الثيل ایى من القياسات السابقة

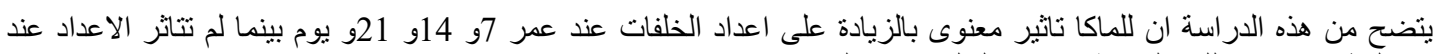
الميلاد و الفطام وكميات اللبن المنتجة واوزان الخلفات عند الميلاد و عند 7 ، 14 ، 21 و 28 يوم. 